\title{
Too many Cooks? Committees in Monetary Policy
}

\author{
HELGE BERGER \\ VOLKER NITSCH
}

\section{CESIFO WORKING PAPER NO. 2274 \\ CATEgORY 6: MONETARY POLICY AND InTERnATIONAL FInANCE APRIL 2008}

\footnotetext{
An electronic version of the paper may be downloaded

- from the SSRN website: www.SSRN.com

- from the RePEc website: - from the CESifo website: 


\title{
Too many Cooks? Committees in Monetary Policy
}

\begin{abstract}
How many people should decide about monetary policy? In this paper, we take an empirical perspective on this issue, analyzing the relationship between the number of monetary policy decision-makers and monetary policy outcomes. Using a new data set that characterizes Monetary Policy Committees (MPCs) in more than 30 countries from 1960 through 2000, we find a U-shaped relation between the membership size of MPCs and inflation; our results suggest that the lowest level of inflation is reached at MPCs with about seven to ten members. Similar results are obtained for other measures, such as inflation variability and output growth. We also find that MPC size influences the success of monetary targeting regimes. In contrast, there is no evidence that either turnover rates of MPC members or the membership composition of MPCs affect economic outcomes.
\end{abstract}

JEL Code: E52, E58, E61.

Keywords: central bank design, monetary policy committee, central bank board, central bank council, governance, inflation.

\author{
Helge Berger \\ Free University Berlin \\ Economics Department \\ Boltzmannstrasse 20 \\ 14195 Berlin \\ Germany \\ helge.berger@fu-berlin.de
}

\author{
Volker Nitsch \\ ETH Zurich \\ KOF Swiss Economic Institute \\ Weinbergstrasse 35 \\ 8092 Zurich \\ Switzerland \\ nitsch@kof.ethz.ch
}

March 26, 2008

We thank numerous colleagues at various central banks for helpful feedback, information, and conversations. For comments, we thank seminar participants at the Reserve Bank of New Zealand and Norges Bank. Anne-Kristin Koch and Dominic Quint provided able research assistance. Berger thanks the IMF for its hospitality. Financial support from the FritzThyssen-Foundation is gratefully acknowledged. The views expressed in this paper are those of the authors and do not necessarily represent those of the IMF or IMF policy. 


\section{Introduction}

The number of people who decide about monetary policy varies considerably across countries. At one extreme, decisions are made by a single person. Examples where the governor alone is responsible for monetary policy include the Bank of Israel and the Reserve Bank of New Zealand. At the other extreme, central banks operate large monetary policy committees (MPCs) that comprise more than a dozen members. ${ }^{1}$ A prominent example is the Governing Council of the European Central Bank which consists of 21 voting members. Similarly, in the U.S. Federal Open Market Committee, 19 members are participating in policy discussions, out of which 12 hold voting rights. Fry, Julius, Mahadeva, Roger, and Sterne (2000) report that 8 (of 82 surveyed) central banks have monetary policy boards with more than 10 members.

The number of monetary policy decision-makers, while generally persistent, also frequently changes over time. In Germany, for instance, the Bundesbank MPC had initially 10 members, which changed to 18 members in the late 1950s and was cut back again to 17 after the 1992 reform. ${ }^{2}$ In Brazil, the central bank reform of the late 1980s effectively reduced MPC size from a maximum of 26 members to 9 members. In the U.K., in contrast, the 1997 reform act took monetary policy decisions out of the hands of the governor and into the hands of a nine member MPC.

With MPCs varying across countries and years, a growing literature aims to quantify their optimal membership size as an important feature of central bank design. While there is a broad consensus that committees make better decisions than individuals, there is much less agreement on how large a committee should be. ${ }^{3}$ Theory suggests that the benefits of increasing MPC size become smaller, and the costs of decision-making increase, as MPCs become larger. The magnitude of these offsetting forces, however, is likely to depend on a variety of factors. As a result, Goodfriend (2005, p. 85) argues that the "efficient size of a policy committee might vary across countries”.

In this paper, we take an empirical perspective on this issue. More specifically, we examine to what extent the economic outcomes of monetary policy are possibly associated with the number of monetary policy decision-makers. To analyze this issue, we have compiled a new data set of the de jure and de facto membership size of MPCs; our unbalanced panel covers, on a yearly basis, more than 30 countries from 1960 through 2000. In addition, since de facto membership is derived from the names, positions, and membership dates of MPC members, we are able to compute the annual turnover rate of MPC membership. Finally, we gathered information on whether the MPC comprises industry representatives, regional delegates or government representatives. In our empirical analysis, we use all these measures to examine the effects of MPC design on inflation (and other economic outcomes), after controlling for other economic and institutional factors.

\footnotetext{
${ }^{1}$ We use the term MPC in the broadest possible sense, describing the board, council, or committee (etc.) making actual monetary policy decisions.

${ }^{2}$ The Bundesbank reform of 1992 prevented a significant increase in the number of voting governors in its Central Bank Council ('Zentralbankrat') due to German unification. Before the reform, each federal state had a representative in the Council, and without reform, membership would have exceeded 22 - a number that, according to the Bundesbank, “would have greatly complicated that body’s decision-making processes” (Deutsche Bundesbank 1992, p. 50).

${ }^{3}$ For surveys of the literature, see, among others, Gerling, Grüner, Kiel and Schulte (2005), Fujiki (2005), Sibert (2006), Vandenbussche (2006), and Berger (2006).
} 
To preview our main results, we find a U-shaped relationship between MPC size and inflation. More precisely, inflation first tends to fall as the number of MPC members increases, but this effect becomes smaller and eventually turns positive as MPCs grow in size. Taken at face value, our estimates imply that the minimum level of inflation is reached at MPCs with about seven to ten members, after holding constant for other factors. Similar results are obtained for other measures of economic outcomes such as inflation variability and output growth. In addition, we find that MPC size affects the success of monetary targeting regimes, as defined by Fatas, Mihov, and Rose (2007). In contrast, there is little evidence that other measures of MPC design, membership turnover rates and the membership composition of MPCs, are robustly associated with economic outcomes.

The remainder of the paper is organized as follows. In Section 2, we review the relevant literature. Section 3 describes our empirical methodology and the data. The heart of our paper is Section 4 which presents the empirical results. Section 5 provides a brief conclusion.

\section{Related Literature}

A sizable literature deals with the merits of smaller or larger MPCs from an applied theoretical and institutional perspective. For instance, Blinder (1998) and Gerlach-Kristen (2006) argue that, when it comes to the efficiency of monetary policy making, 'bigger may be better' because a more numerous MPC will process information on the state of the economy more effectively than an individual; in a group, information is pooled, there may be even cooperation in information processing, and extreme decisions are likely to be avoided. ${ }^{4}$ Blinder and Morgan (2005) and Lombardelli, Proudman, and Talbot (2005) provide supporting evidence based on experimental research. However, the gains from larger MPCs do not remain unbalanced. The literature surveyed in Sibert (2006) suggests that the advantages in information processing are likely to diminish as MPC size increases because members may have an incentive to 'free-ride' on the efforts of others. Similarly, Berger (2002, 2006) argues that in larger committees members will spend considerably more time 'sounding each other out' bilaterally before or during meetings so that decision-making costs are growing (possibly exponentially) in MPC membership. ${ }^{5,6}$

Another set of papers takes a more empirical approach on the design of MPCs. Berger, Nitsch, and Lybek (2008) analyze differences in the size of MPCs in a cross-section sample of 84 countries. Examining a large number of possible determinants, they find that larger and more heterogeneous countries, countries with stronger democratic institutions, countries with floating exchange rate regimes, and independent central banks with more staff tend to have larger MPCs; see also Erhart and Vasquez-Paz (2007). ${ }^{7}$ Erhart, Lehment, and Vasquez-Paz

\footnotetext{
${ }^{4}$ See also the discussion in Blinder (1998), Berk and Beirut (2004), and Riboni and Ruge-Murcia (2006).

${ }^{5}$ The governor of the Bank of England, Mervyn King, has recently defended the membership size of nine members in the MPC of the Bank of England by arguing: "I do think that more than nine would run the risk of making the process much less effective because a conversation among the nine is a key part of it and to have many more people would run the risk, as I think happens in somewhat larger councils that set policy, that some people have more say than others; there may be inner deliberations that take place because a very large body is simply too big to have a sensible discussion.” (UK House of Commons, 2007, p. 29)

${ }^{6}$ The weight of these arguments depends also on other institutional features of the MPC. Relevant factors include, for instance, whether decisions are consensus-based, which voting rules are in place, and the leadership provided by the MPC chairperson. On these and related issues see, for instance, von Hagen and Brückner (2001), Gersbach and Pachl (2004), Gerlach-Kristen (2006), and Blinder and Morgan (2007). For a recent review of issues in MPC design, see Blinder (2007)

${ }^{7}$ These findings are essentially positive in nature. To give them normative content, one must assume that observed MPC sizes are the outcome of optimal central bank design decisions and argue that larger and more
} 
(2007) examine differences in the volatility of inflation for MPCs with more or less than five members. Exploring cross-country evidence for 75 countries, they find that inflation volatility is higher in (the small subset of) countries with MPC sizes below five. ${ }^{8}$

More broadly, our paper is also close in spirit to the large literature that has empirically examined the effects of institutional features of central banking on monetary policy and policy outcomes. Some of these papers focus on features of central bank design such as central bank independence (see, among others, Cukierman, Webb, and Neyapti 1992, Campillo and Miron 1997, de Haan and Kooi 2000), transparency in monetary policy (e.g., Fatas, Mihov, and Rose 2007), or the personal background of central bankers (Göhlmann and Vaubel 2007). Other papers analyze the role of monetary policy strategies such as inflation targeting or exchange rate regime choice (e.g., Mishkin and Schmidt-Hebbel 2007, Levy-Yeyati und Sturzenegger 2001, 2003).

\section{Methodology and Data}

Our principle approach is to explore the link between the membership size of a central bank's monetary policy decision-making body and monetary policy outcomes, in particular the level of inflation. Price stability or low inflation is among the more prominent targets of central banks around the world. Indeed, in many cases, low inflation (either directly or through intermediate targets) is the overarching goal of monetary policy; see Fry, Julius, Mahadeva, Roger, and Sterne (2000) for a survey. In addition to the level of inflation, however, we also look at inflation variability and output growth (mainly as a robustness check). To the extent that there is indeed an empirical association between MPC size and economic outcomes, our findings may have the potential of decisively informing the debate on the optimal size of MPCs.

To examine the effect of committee size on monetary policy outcomes, we apply various empirical techniques. First, we conduct a simple event-study analysis that explores the effects of variations in committee size over time. The results are informative but somewhat limited by the small number of sizable MPC size changes in our sample. Therefore, in a second step, we make systematic use of the panel nature of our data, looking at the effects of MPC size on policy outcomes across time and countries.

Our panel approach follows the example of Fatas, Mihov and Rose (2007); that is, we estimate equations of the form:

$$
\Pi_{\mathrm{i}, \mathrm{t}+1}=\alpha+\beta \text { MPCsize }_{\mathrm{i}, \mathrm{t}}+\Sigma_{\mathrm{j}} \gamma_{\mathrm{j}} \mathrm{X}_{\mathrm{i}, \mathrm{t}}+\Sigma_{\mathrm{k}} \delta_{\mathrm{k}} \mathrm{Y}_{\mathrm{i}, \mathrm{t}}+\varepsilon_{\mathrm{i}, \mathrm{t}},
$$

where $\Pi_{i, t+1}$ denotes the inflation rate of country $i$ at time $t+1$, MPCsize is the membership size of the MPC, $X$ is a set of other central bank features such as the (de jure) existence of a quantitative monetary target and the ability of a given central bank to meet that target in a given year, $\mathrm{Y}$ is a set of country-specific characteristics that may (potentially) affect inflation such as a country's openness to international trade and the current state of the business cycle, and $\varepsilon$ is a normally distributed disturbance.

\footnotetext{
heterogeneous currency areas should indeed have larger MPCs. Erhart and Vasquez-Paz (2007) provide an interesting attempt in that direction.

${ }^{8}$ In their sample, eight out of 75 countries have MPCs with less than five members. Most of these countries are small in size.
} 
The relevant data are obtained from various sources. At the heart of our data set is a new (unbalanced) panel that covers the identities of MPC members for 33 central banks from 1960 to 2006. These (raw) data were compiled in a three-step procedure. First, we identify the central bank's monetary policy decision-making body, the MPC. This information is typically available from the central bank law but, where necessary, we cross-checked the information with central bank officials. In most cases, the committee that runs a central bank's day-to-day operations also takes de jure responsibilities for monetary policy decision-making. ${ }^{9}$ Second, we extract relevant information describing the MPC from central bank laws. Features that are frequently defined in the law include the membership size, the composition of the decisionmaking body, the frequency of meetings, voting rules and majorities, and specific requirements on individual members (e.g., nationality, educational background). For instance, we distinguish in our analysis between voting and non-voting members. We also construct a set of other measures of potential interest, including the de jure MPC size and the fraction of industry, regional, or government representatives in the committee.

Finally, using a variety of sources such as annual reports and other forms of central bank communication, we identify individual MPC members and their positions. Since we have information on the entry and exit dates of individuals, we use this data to construct measures of de facto MPC size and MPC membership turnover.

Other institutional and economic data are mainly obtained from standard sources. We rely on Fatas, Mihov, and Rose (2007) for information on the presence of de jure monetary policy targets and whether a particular target was met in practice. Also for most economic data, which often originally stems from the World Bank's World Development Indicators, we have turned to Fatas, Mihov, and Rose's extractions from standard databases to allow full comparability of our results. A data appendix provides a detailed list of the variables used in the empirical analysis and a description of the sources.

\section{Empirical Results}

\section{$\underline{\text { 4.1 Descriptive Statistics }}$}

We begin by describing our data on MPC membership size in more detail. Figure 1 portrays the evolution of de facto MPC size over time. The figure graphs the average membership size for the full sample and, since data availability varies across years, also for different groups of countries for which we have data covering similar periods. The averages are based on the full membership size of committees (i.e., including non-voting MPC members) since, on a practical level, all MPC members are likely to contribute to MPC decisions. However, all of our empirical results are robust to using only voting members.

There are (at least) three notable observations. First, average MPC size is fairly persistent. While there are some short-term fluctuations due to vacancies or minor adjustments, there are very few radical changes in average committee size, which consistently averages between six and eight members since the late 1950s. A notable exception is Brazil where the size (and composition) of the monetary policy committee has fluctuated enormously.

\footnotetext{
${ }^{9}$ We ignore any informal or semi-official arrangements in the preparation of monetary policy decisions (e.g., when the governor or the board holds consultations before taking decisions) mostly because this type of arrangements may be easily changed on an ad hoc basis and is, in the end, very hard to document.
} 
Figure 1: MPC Membership Size

(a) Sample average

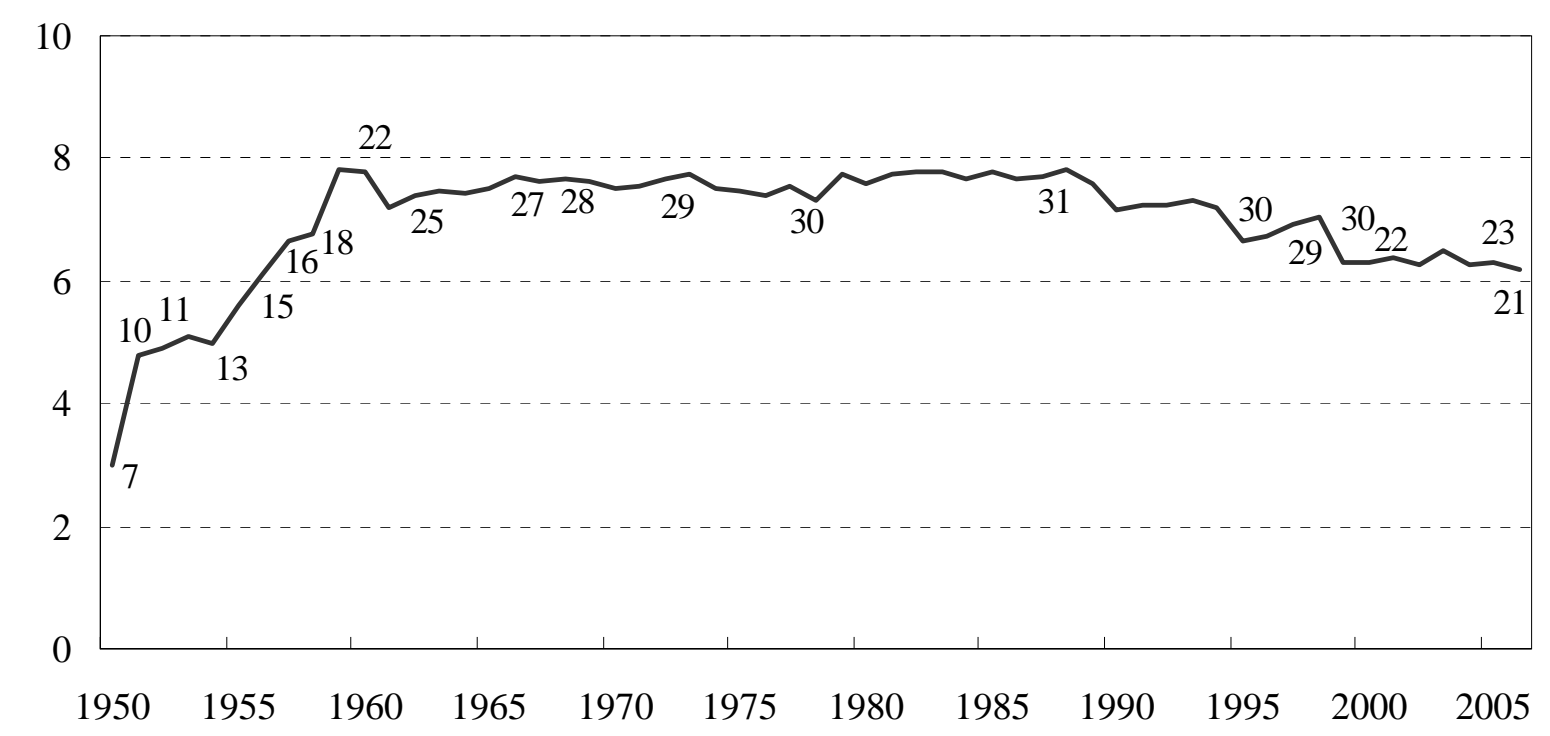

(b) Average for various groups of countries

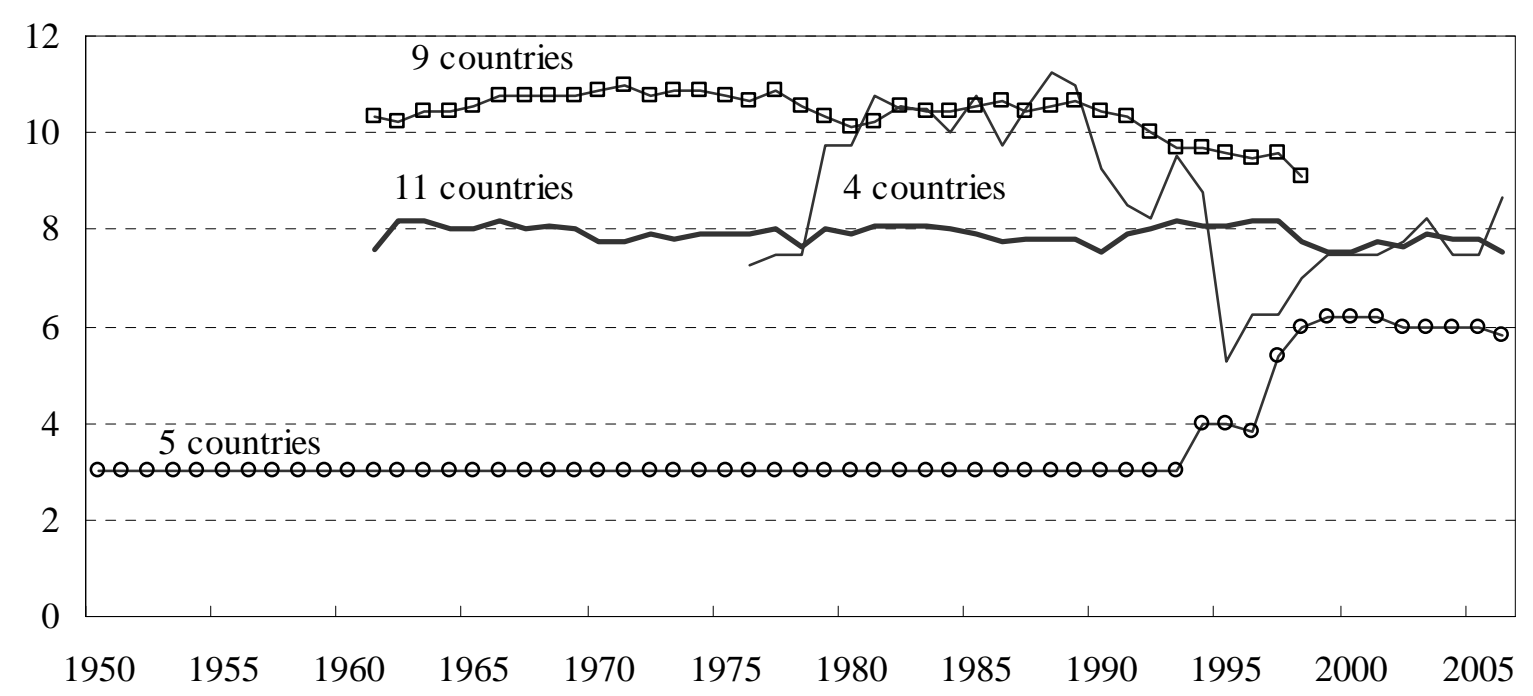

Notes: Panel (a) plots the average membership size of monetary policy decision-making bodies; the numbers denote sample size. Panel (b) depicts the average MPC size for various groups of countries. Countries were grouped according to data availability. The groups are as follows. 5 countries: Canada, Denmark, Japan, and Switzerland, and U.K.; 11 countries: Australia, Iceland, Israel, Korea, Malaysia, New Zealand, Norway, Sweden, Trinidad \& Tobago, Turkey, U.S.; 4 countries: Botswana, Brazil, Mauritius, and Singapore; 9 countries (euro area): Austria, Belgium, Finland, France, Germany, Ireland, Italy, Netherlands, Portugal. 
Second, to the extent that there is change over time, it appears that MPCs are converging in membership size. While the countries in our sample are basically grouped randomly according to data availability, it is interesting to note that the group of countries with initially small MPCs (labeled ' 5 countries') experienced on average an increase in membership size; this group of countries includes, among others, the Bank of England which has newly established an MPC in 1997. In contrast, groups with relatively large MPCs have tended to reduce membership size.

Third, the average MPC size of central banks in European countries that later joined the euro area (labeled as ' 9 countries' in Figure 1) appears to have been, on average, disproportionately large. Especially in small open economies such as Austria, Belgium, Ireland and Portugal, the decision-making bodies were relatively large, often comprising more than 10 members.

\section{$\underline{4.2 \text { Event Study }}$}

Next, we examine episodes of major changes in MPC membership size in greater detail. In particular, we identify episodes when the de facto size of a MPC has increased or decreased by more than two members in a given year. ${ }^{10}$ Taking an event study approach, we then analyze (in univariate fashion) the dynamic behavior of variable(s) of interest before and after that change.

Figure 2 graphs the size of committees before and after major MPC size changes. There are five episodes of large and rapid decreases in committee size in our sample and three episodes of enlargement. During those adjustments, committee size has changed, on average, by six members. Interestingly, it turns out that committees whose membership size was reduced were initially larger than the average, while committees where membership size has sizably increased were initially disproportionately small. This finding provides some additional evidence for a process of convergence in committee size that we have already observed above.

Figure 3 illustrates the dynamics of inflation and output growth during episodes of decreasing ('fewer members') and increasing ('more members') MPC size. For each outcome variable, we present two sets of results. The upper panel contains results derived from the full sample; analogous graphs for a reduced sample, where the high-inflation countries Argentina and Brazil are excluded, are presented in the lower panel. As shown, inflation tends to be lower after a reduction in MPC size, while there is little noticeable change after an enlargement of MPCs. However, these results crucially depend on the experiences of Argentina and Brazil; when the two high-inflation countries are excluded, this pattern disappears. For real GDP growth, results appear to be slightly stronger. A decrease in MPC size tends to benefit growth, while MPC enlargement is associated with lower growth, irrespective of the sample.

\footnotetext{
${ }^{10}$ Applying other selection criteria would yield essentially identical results. For instance, almost all of these changes were accompanied by amendments in central bank law, while adjustments in de jure committee size have sometimes led to little real world changes because of existing vacancies (e.g., in Germany). Also, choosing a relative (instead of absolute) cut-off makes little difference because membership size of small committees has rarely changed.
} 
Figure 2: Episodes of Major Changes in MPC Membership Size
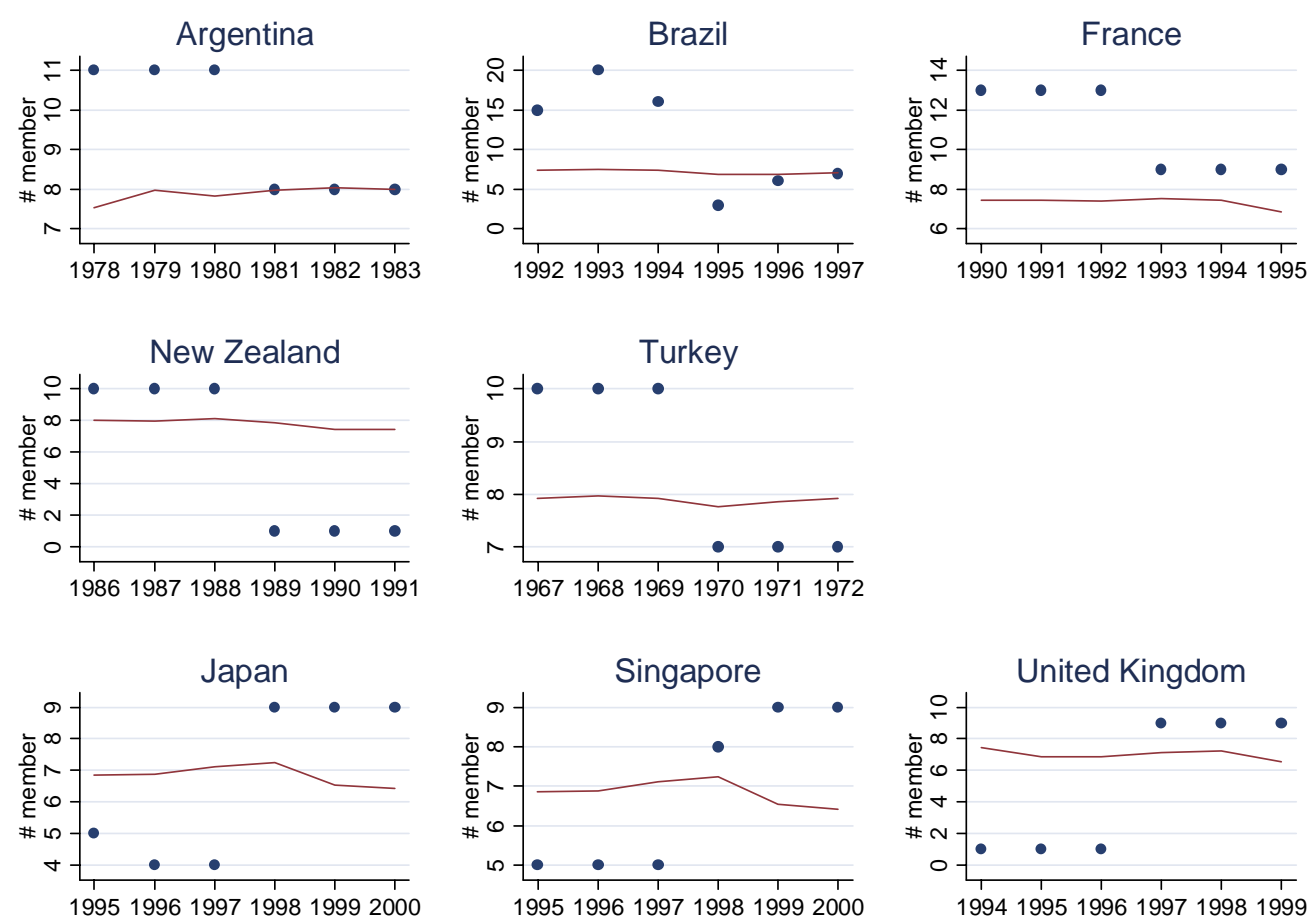

Notes: The dots show the number of de facto voting members; lines represent, for comparison, the sample average membership size of MPCs. 
Figure 3: Inflation and Growth around Large MPC Changes: Event Study

(a) Inflation
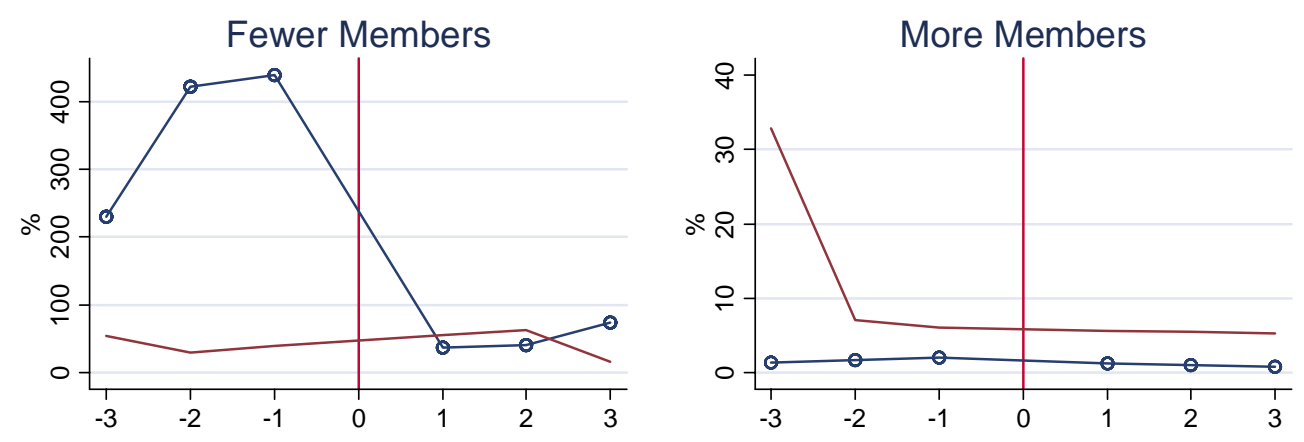

Fewer Members

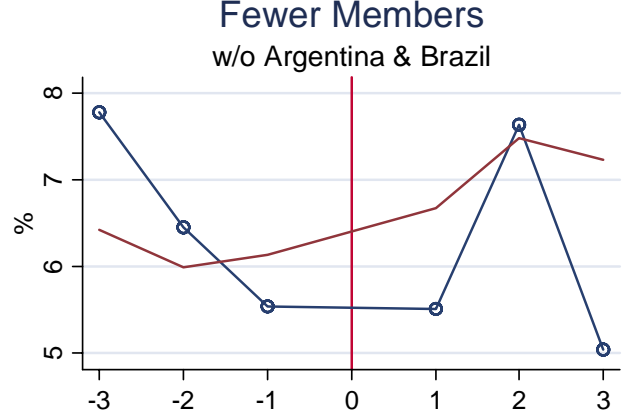

More Members

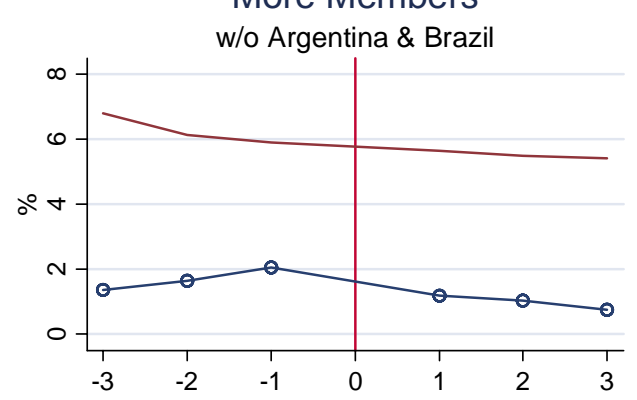

(b) Real GDP growth
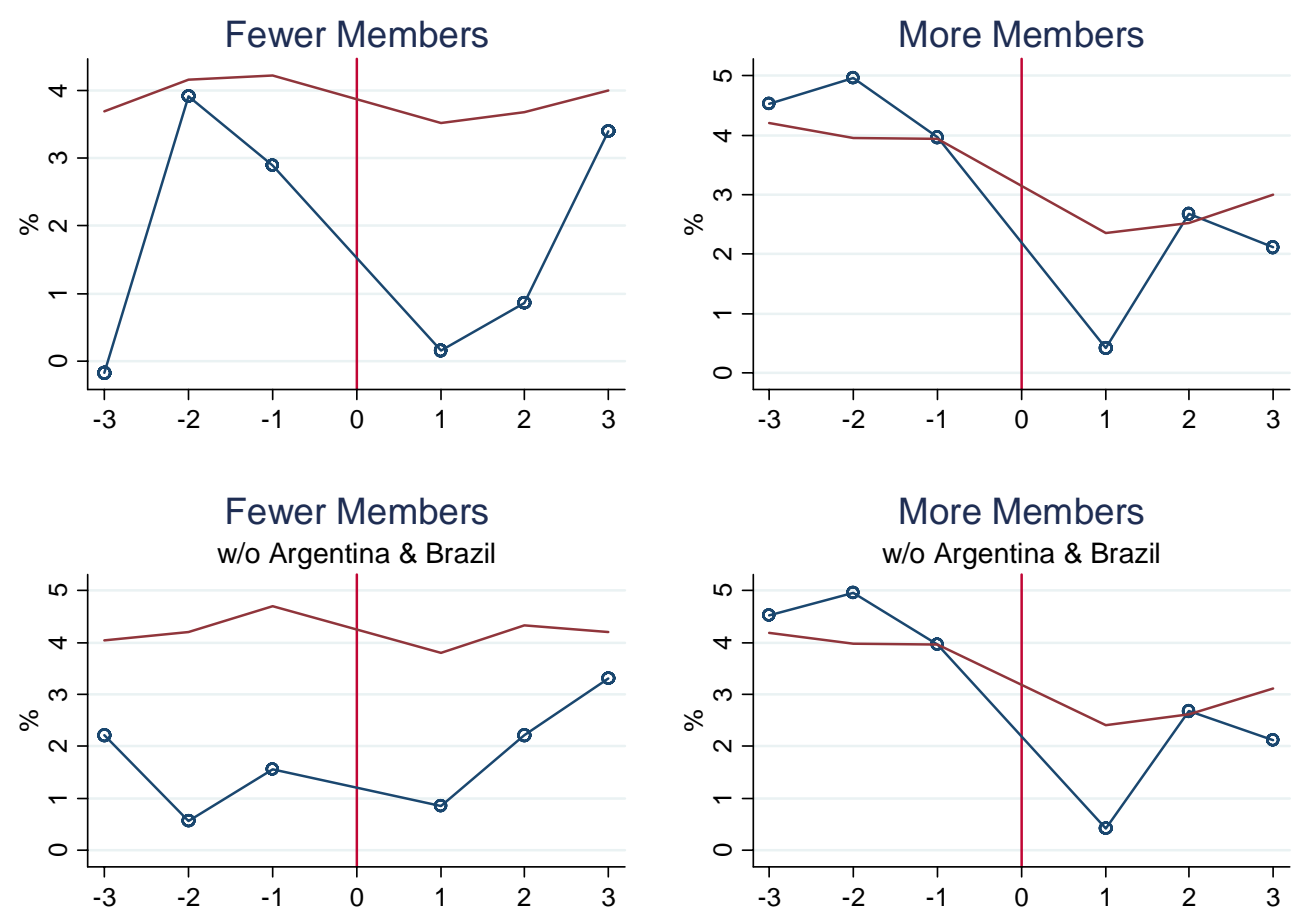

Notes: Dotted lines show averages of the variable of interest for central banks with large changes in membership size; lines represent, for comparison, the sample averages. 
While these findings are generally informative, any linkage between MPC size and policy outcomes is likely to be conditional on other factors. For instance, if there is indeed an optimal level of MPC size (as suggested by the theoretical literature briefly reviewed in Section 2), a change in membership size should lower inflation only if initial MPC size is further away from its optimum. In the following, we examine the relationship between MPC characteristics and various policy outcomes in more detail.

\subsection{Regression Analysis}

To take full account of the panel nature of our data, we follow Fatas, Mihov, and Rose (2007) and estimate the augmented inflation model in (1) using OLS. In our default specification, the dependent variable is a country's annual rate of inflation (in percentage points) in the following year; this timing structure helps to limit potential simultaneity bias. We initially exclude Argentina and Brazil, two outliers in our sample that experienced inflation rates of more than 1,000 percent. $^{11}$

\section{The impact of MPC size on inflation}

Table 1 presents our baseline estimation results. The coefficient of interest is the estimate of $\beta$ which captures the effect of the de facto number of voting members in a monetary policy committee on a country's inflation rate. In the linear specification in column 1, the estimated $\beta$ coefficient is negative, statistically significant and economically relevant, implying that larger committees are typically associated with lower inflation. The point estimate of -0.25 indicates that for any additional member in the monetary policy-making committee annual inflation is reduced by, on average, a quarter of a percentage point. Taken at face value, this estimate seems to support the notion that larger MPCs reach better policy decisions (leading to lower inflation) than smaller groups or a single central banker. ${ }^{12}$

Still, it is not necessarily clear that group performance is a linear function of membership size. In fact, it has been frequently argued that the quality of MPC decisions may decrease as additional group members are added due to coordination problems and distorting incentives in information processing; see, for instance, Sibert (2006) and Berger (2006).

Therefore, to identify possible nonlinearities, we add a quadratic term of MPC size to our estimation model. As shown in the next column, this extension improves the empirical fit of the regression. The linear and quadratic coefficients are indeed highly significant and take opposite signs. Our estimates indicate that moving from an individual decision-maker to a decision-making body with ten members is associated with a decline in inflation by about 8 percentage points, an effect that is completely reversed when membership size rises further to 19 members. In fact, committees with more than 20 members appear to be associated with even higher inflation than for an individual central banker. Thus, consistent with the theory of optimal committee size, the positive effect on inflation dies off and eventually becomes negative as committee size increases.

\footnotetext{
${ }^{11}$ Temple (1998) has highlighted the role of extreme and influential observations in this literature. Moreover, excluding Argentina and Brazil is also the approach taken by Fatas, Mihov, and Rose (2007).

${ }^{12}$ It should be noted that , for most countries and periods in our sample, inflation was clearly (and sometimes highly) positive, implying that a reduction in inflation was typically beneficial for the economy.
} 
Table 1: Baseline results and full sample

\begin{tabular}{|l|l|l|l|l|}
\hline Sample & \multicolumn{2}{|c|}{ Baseline } & \multicolumn{2}{c|}{$\begin{array}{c}\text { Full } \\
\text { (with Argentina, } \\
\text { Brazil) }\end{array}$} \\
\hline & \multicolumn{2}{|c|}{} & & \\
\hline De Facto Membership & $-0.24^{* *}$ & $-2.18^{*}$ & $5.63^{*}$ & $-17.7 \#$ \\
& $(0.08)$ & $(0.93)$ & $(2.58)$ & $(9.7)$ \\
\hline De Facto Membership Squared & & $0.11^{*}$ & & $1.19 \#$ \\
& & $(0.05)$ & & $(0.61)$ \\
\hline De Jure Quant. Monetary & $-12.7^{* *}$ & $-14.2^{* *}$ & $-127.1^{* *}$ & $-128.9^{* *}$ \\
Target & $(3.7)$ & $(4.2)$ & $(36.2)$ & $(36.0)$ \\
\hline Quant. Monetary Success & $-3.63^{* *}$ & $-3.19^{* *}$ & -3.07 & 2.04 \\
& $(0.94)$ & $(0.95)$ & $(5.18)$ & $(6.07)$ \\
\hline Openness (\% GDP) & 0.003 & 0.003 & -0.10 & -0.10 \\
& $(0.007)$ & $(0.007)$ & $(0.08)$ & $(0.08)$ \\
\hline Budget (\% GDP) & $-0.85^{*}$ & $-0.82^{* *}$ & -2.06 & -1.35 \\
& $(0.33)$ & $(0.31)$ & $(1.92)$ & $(1.52)$ \\
\hline Business Cycle & -0.008 & -0.09 & $-7.86 \#$ & $-8.23 \#$ \\
(Growth -Avg Growth) & $(0.200)$ & $(0.21)$ & $(4.24)$ & $(4.27)$ \\
\hline Log Real GDP per capita & $-4.62^{* *}$ & $-5.34^{* *}$ & $-48.7^{* *}$ & $-50.0^{* *}$ \\
& $(1.26)$ & $(1.14)$ & $(14.3)$ & $(14.2)$ \\
\hline Log Real GDP & $-0.89 \#$ & $-1.53^{*}$ & 5.13 & -2.60 \\
& $(0.52)$ & $(0.76)$ & $(3.32)$ & $(4.63)$ \\
\hline & & & & \\
\hline Observations & 815 & 815 & 842 & 842 \\
\hline Adj. R-squared & 0.21 & 0.23 & 0.13 & 0.16 \\
\hline
\end{tabular}

Notes: OLS estimation. Dependent variable is lead of inflation. **, * and \# denote significant at the 1, 5 and 10 percent level, respectively. Membership size effects are jointly significant at 6 percent level in the full sample. 
This finding is further strengthened by results based on the full sample, tabulated in the two columns on the right of Table 1. Extending the sample to also include Argentina and Brazil, two countries not only with (extremely) high inflation but also (very) large committees, changes the sign of the $\beta$ coefficient in the linear estimation so that, effectively, the highinflation experience of large committees dominates the results. Still, it is reassuring to note that the results for the non-linear model remain qualitatively unchanged with the full sample is analyzed.

Besides MPC size, our model includes various (standard) covariates of inflation. For instance, following Fatas, Mihov, and Rose (2007), we control for the presence of quantitative targets for monetary policy and whether these targets have been reached. The negative and mostly significant coefficients on these variables indicate that transparent goals for monetary policy indeed help to lower inflation. Also, countries with higher per capita income and more prudent fiscal policies tend to have significantly lower inflation rates. In contrast, trade openness and the economic size of a country (proxied by real GDP) are uncorrelated with inflationary outcomes. Deviations from average GDP growth are at best weakly associated with inflation (in the extended sample that includes Brazil and Argentina).

Figure 4 provides a graphical illustration of the nonlinear relationship between MPC size and inflation outcome. More importantly, the plots easily allow identifying the membership size that minimizes inflation (conditional on other factors). As shown, our baseline estimates indicate that MPCs with ten members are most successful in curbing inflation. When also Argentina and Brazil are included, the MPC size that minimizes inflation is seven members. ${ }^{13}$ Interestingly, in practice, a majority of central bank MPCs appears to fall exactly into this size range; see Fry, Julius, Mahadeva, Roger, and Sterne (2000).

We have performed extensive sensitivity analyses. Table 2 applies various panel estimators, controlling for time-fixed effects and country-fixed effects. With these modifications, the relationship between MPC size and inflation is strengthened when time-fixed effects are added but loses significance when the regression includes country-fixed effects. As a result, the observed empirical association between MPC size and inflation appears to be mainly driven by the cross-country variation in our sample; Fatas, Mihov, and Rose (2007) report similar findings for the effects of quantitative monetary targets. In unreported results, we have also experimented with more aggregate (index) measures of MPC size to filter out minor variations in membership size over time; reassuringly, these estimates turn out to be much less influenced by the inclusion of country-fixed effects.

\footnotetext{
${ }^{13}$ This result is mostly driven by the fact that the two high inflation countries were also characterized by relatively large MPCs during most of the sample period.
} 
Figure 4: Simulated Effect of MPC Size on Inflation

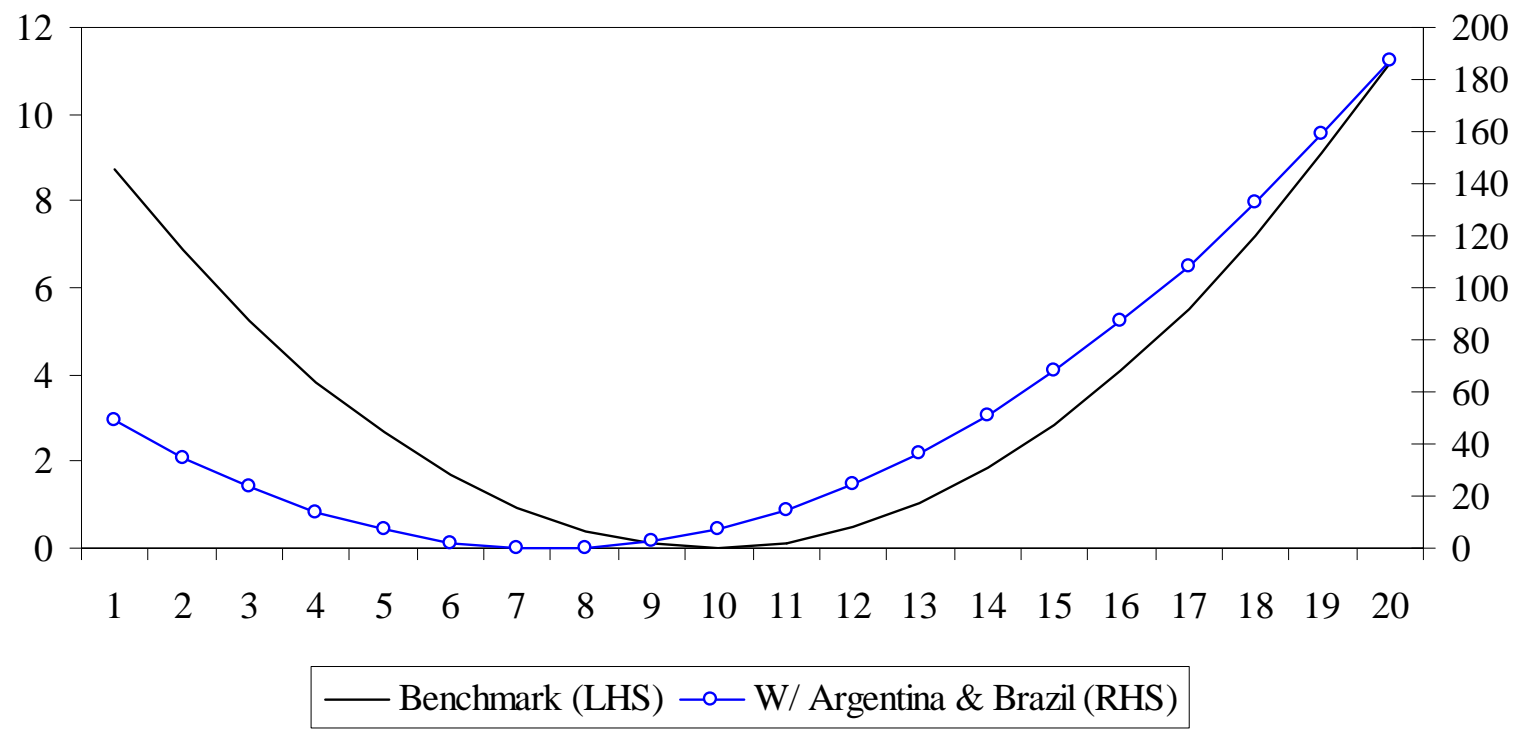

Notes: Inflation in percent. Simulations are based on the estimation results reported in Table 1 keeping all other variables constant. The minimum inflation rate has been calibrated to zero. 
Table 2: Alternative estimation techniques

\begin{tabular}{|l|l|l|l|l|}
\hline Estimation & \multicolumn{2}{|l|}{ Year fixed effects } & \multicolumn{2}{l|}{ Country fixed effects } \\
\hline & & & & \\
\hline De Facto & $-0.27^{* *}$ & $-2.54^{* *}$ & -0.10 & 0.43 \\
Membership & $(0.08)$ & $(0.93)$ & $(0.21)$ & $(0.49)$ \\
\hline De Facto & & $0.13^{* *}$ & & -0.03 \\
Membership Squ'd & & $(0.05)$ & & $(0.03)$ \\
\hline De Jure Quant. & $-12.9^{* *}$ & $-14.8^{* *}$ & $-15.4^{* *}$ & $-15.4^{* *}$ \\
Monetary Target & $(3.8)$ & $(4.3)$ & $(5.3)$ & $(5.3)$ \\
\hline Quant. Monetary & $-2.98^{* *}$ & $-1.70^{* *}$ & -0.01 & -0.05 \\
Success & $(1.03)$ & $(1.01)$ & $(1.43)$ & $(1.42)$ \\
\hline Openness (\% GDP) & -0.005 & -0.010 & $0.10^{*}$ & $0.10^{*}$ \\
& $(0.009)$ & $(0.008)$ & $(0.04)$ & $(0.04)$ \\
\hline Budget (\% GDP) & $-0.71^{*}$ & $-0.67^{*}$ & $-0.85^{*}$ & $-0.86^{*}$ \\
& $(0.33)$ & $(0.30)$ & $(0.34)$ & $(0.34)$ \\
\hline Business Cycle & 0.05 & 0.03 & -0.04 & -0.03 \\
(Growth-Avg Grth) & $(0.23)$ & $(0.23)$ & $(0.18)$ & $(0.18)$ \\
\hline Log Real GDP per & $-4.68^{* *}$ & $-6.10^{* *}$ & $-37.4^{* *}$ & $-37.3^{* *}$ \\
capita & $(1.48)$ & $(1.27)$ & $(11.5)$ & $(11.5)$ \\
\hline Log Real GDP & -0.82 & $-1.58^{*}$ & $23.5^{*}$ & $23.4^{*}$ \\
& $(0.52)$ & $(0.76)$ & $(9.3)$ & $(9.3)$ \\
\hline & & & & \\
\hline Observations & 815 & 815 & 815 & 815 \\
\hline Adj. R-squared & 0.25 & 0.27 & & \\
\hline Within R-squared & & & 0.17 & 0.17 \\
\hline
\end{tabular}

Notes: Baseline sample. OLS estimation. Dependent variable is lead of inflation. ${ }^{* *},{ }^{*}$ and \# denote significant at the 1, 5 and 10 percent level, respectively. 


\section{The impact of MPC size on inflation variability and growth}

Table 3 explores alternative measures for the success of monetary policy. Our key findings seem strongly robust. For instance, MPC size is not only associated with the level of inflation but also affects (in similar fashion) inflation variability. That is, having more members in the MPC is on average associated with lower inflation variability, while the non-linear specification again suggests a U-shaped relationship between MPC size and the monetary policy outcome. Similarly, we find a nonlinear association between MPC size and GDP growth; enlarging a MPC initially tends to increase output growth, but this effect is reversed for large committees. In sum, these findings imply that any gains from varying MPC size in terms of lower and less volatile inflation do not involve a trade-off with output growth; quite on the contrary, our results suggest that there is a consistent nonlinear association between MPC size and monetary policy outcomes.

\section{The role of other MPC characteristics}

In Table 4, we analyze the effect of other measures that characterize a central bank's decisionmaking body on inflation. We begin with replacing our continuous measure of de facto membership size with a set of binary dummy variables that group MPCs into size quartiles. The results confirm our earlier finding of a nonlinear relationship between committee size and inflation. Having sorted MPCs by increasing membership size and using the top quartile as control group, moving to a quartile that comprises larger MPCs tends to reduce inflation although this effect becomes smaller as MPC size increases. Next, we substitute de facto MPC membership size with MPC size as specified (de jure) in the central bank law. ${ }^{14}$ The results are basically identical to our default specification, though statistically slightly weaker. We also restrict our measure of de facto committee size to include only voting committee members. Again, the results are basically unchanged. ${ }^{15}$

Moving beyond measures of membership size, we also explore two measures that capture the extent of MPC membership turnover. More specifically, we examine the effects of the frequencies of changes of MPC membership and the effects of changes of the chairman of the MPC (that is, the central bank governor) on inflation. ${ }^{16}$ None of the estimated coefficients, however, is statistically different from zero-a finding that is perhaps not terribly surprising since we are unable to distinguish between regular and irregular changes in MPC membership. Also, Sturm and de Haan (2001) and Dreher, de Haan, and Sturm (2007) find that governor turnover rates are, at best, weakly associated with inflation.

\footnotetext{
${ }^{14}$ When a range is given, we use the mid-point.

${ }^{15}$ When only voting members are considered, our estimation results indicate that inflation is minimized at an MPC size of nine members.

${ }^{16}$ To the best of our knowledge, this is the first attempt to evaluate the relevance of MPC membership turnover for economic outcomes. The literature on central bank turnover after Cukierman (1992) has focused exclusively on governors.
} 
Table 3: Other dependent variables

\begin{tabular}{|l|l|l|l|l|}
\hline Dependent variable & \multicolumn{2}{|l|}{ Inflation variability } & \multicolumn{2}{l|}{ Output growth } \\
\hline & & & & \\
\hline De Facto & $-0.08^{* *}$ & $-0.34^{* *}$ & $-0.015 \#$ & $0.07^{*}$ \\
Membership & $(0.02)$ & $(0.10)$ & $(0.008)$ & $(0.04)$ \\
\hline De Facto & & $0.015^{* *}$ & & $-0.005^{* *}$ \\
Membership Squ'd & & $(0.005)$ & & $(0.002)$ \\
\hline De Jure Quant. & -0.26 & -0.47 & 0.005 & 0.08 \\
Monetary Target & $(0.55)$ & $(0.56)$ & $(0.168)$ & $(0.17)$ \\
\hline Quant. Monetary & $-1.75^{* *}$ & $-1.69^{* *}$ & $-0.67^{* *}$ & $-0.69^{* *}$ \\
Success & $(0.35)$ & $(0.35)$ & $(0.13)$ & $(0.13)$ \\
\hline Openness (\% GDP) & 0.002 & $0.002 \#$ & $0.015^{* *}$ & $0.015^{* *}$ \\
& $(0.001)$ & $(0.001)$ & $(0.001)$ & $(0.001)$ \\
\hline Budget (\% GDP) & $-0.16^{* *}$ & $-0.15^{* *}$ & $0.03^{* *}$ & $0.03^{* *}$ \\
& $(0.02)$ & $(0.02)$ & $(0.01)$ & $(0.01)$ \\
\hline Business Cycle & -0.06 & -0.07 & $0.95^{* *}$ & $0.95^{* *}$ \\
(Growth-Avg Grth) & $(0.06)$ & $(0.06)$ & $(0.02)$ & $(0.02)$ \\
\hline Log Real GDP per & $-2.30^{* *}$ & $-2.40^{* *}$ & $-2.22^{* *}$ & $-2.19^{* *}$ \\
capita & $(0.34)$ & $(0.33)$ & $(0.08)$ & $(0.07)$ \\
\hline Log Real GDP & -0.09 & -0.17 & $0.11^{* *}$ & $0.14^{* *}$ \\
& $(0.10)$ & $(0.11)$ & $(0.04)$ & $(0.04)$ \\
\hline & & & & \\
\hline Estimation & OLS & OLS & OLS & OLS \\
\hline Observations & 815 & 815 & 818 & 818 \\
\hline Adj. R-squared & 0.28 & 0.28 & 0.89 & 0.89 \\
\hline
\end{tabular}

Notes: Baseline sample. OLS estimation. ${ }^{* *}$, * and \# denote significant at the 1, 5 and 10 percent level, respectively. 
Table 4: Other measures of MPC size

\begin{tabular}{|c|c|c|c|c|c|c|c|}
\hline $\begin{array}{l}\text { De Facto Size } \\
\text { (Second Quartile) }\end{array}$ & $\begin{array}{l}-3.37 \\
(2.50)\end{array}$ & & & & & & \\
\hline $\begin{array}{l}\text { De Facto Size } \\
\text { (Third Quartile) }\end{array}$ & $\begin{array}{l}-6.07^{* *} \\
(2.10)\end{array}$ & & & & & & \\
\hline $\begin{array}{l}\text { De Facto Size } \\
\text { (Fourth Quartile) }\end{array}$ & $\begin{array}{l}-1.84^{*} \\
(0.76)\end{array}$ & & & & & & \\
\hline $\begin{array}{l}\text { De Jure } \\
\text { Membership }\end{array}$ & & $\begin{array}{l}-0.38 * * \\
(0.09)\end{array}$ & $\begin{array}{l}-1.57 \# \\
(0.81)\end{array}$ & & & & \\
\hline $\begin{array}{l}\text { De Jure } \\
\text { Membership Squ'd }\end{array}$ & & & $\begin{array}{c}0.07 \\
(0.04)\end{array}$ & & & & \\
\hline $\begin{array}{l}\text { De Facto Voting } \\
\text { Membership }\end{array}$ & & & & $\begin{array}{l}-0.22 * * \\
(0.09)\end{array}$ & $\begin{array}{l}-1.45^{*} \\
(0.71)\end{array}$ & & \\
\hline $\begin{array}{l}\text { De Facto Voting } \\
\text { Membership Squ'd }\end{array}$ & & & & & $\begin{array}{r}0.08 \# \\
(0.04)\end{array}$ & & \\
\hline $\begin{array}{l}\text { Membership } \\
\text { Turnover Rate }\end{array}$ & & & & & & $\begin{array}{l}-0.56 \\
(3.05)\end{array}$ & \\
\hline $\begin{array}{l}\text { Governor Turnover } \\
\text { Dummy }\end{array}$ & & & & & & & $\begin{array}{c}0.89 \\
(1.62)\end{array}$ \\
\hline $\begin{array}{l}\text { De Jure Quant. } \\
\text { Monetary Target }\end{array}$ & $\begin{array}{c}-13.6^{* *} \\
(4.2) \\
\end{array}$ & $\begin{array}{c}-12.9 * * \\
(3.7)\end{array}$ & $\begin{array}{c}-14.4^{* *} \\
(4.4) \\
\end{array}$ & $\begin{array}{c}-12.9 * * \\
(3.7)\end{array}$ & $\begin{array}{c}-13.7^{* *} \\
(4.1) \\
\end{array}$ & $\begin{array}{c}-13.0 * * \\
(3.8) \\
\end{array}$ & $\begin{array}{c}-12.9^{* *} \\
(3.7) \\
\end{array}$ \\
\hline $\begin{array}{l}\text { Quant. Monetary } \\
\text { Success }\end{array}$ & $\begin{array}{l}-3.98 * * \\
(0.98)\end{array}$ & $\begin{array}{l}-3.31^{* *} \\
(0.94)\end{array}$ & $\begin{array}{l}-2.80 * * \\
(0.99)\end{array}$ & $\begin{array}{l}-3.52 * * \\
(0.93)\end{array}$ & $\begin{array}{l}-3.44^{* *} \\
(0.97)\end{array}$ & $\begin{array}{l}-4.01^{* *} \\
(1.00)\end{array}$ & $\begin{array}{c}-3.91 * * \\
(0.98)\end{array}$ \\
\hline Openness (\% GDP) & $\begin{array}{c}0.001 \\
(0.008)\end{array}$ & $\begin{array}{c}0.006 \\
(0.008)\end{array}$ & $\begin{array}{c}0.006 \\
(0.008)\end{array}$ & $\begin{array}{c}0.003 \\
(0.007)\end{array}$ & $\begin{array}{c}0.003 \\
(0.007)\end{array}$ & $\begin{array}{c}0.003 \\
(0.008)\end{array}$ & $\begin{array}{c}0.004 \\
(0.007)\end{array}$ \\
\hline Budget (\% GDP) & $\begin{array}{l}-0.88^{* *} \\
(0.33) \\
\end{array}$ & $\begin{array}{l}-0.84^{*} \\
(0.33)\end{array}$ & $\begin{array}{l}-0.80^{* *} \\
(0.30) \\
\end{array}$ & $\begin{array}{l}-0.85 * * \\
(0.33)\end{array}$ & $\begin{array}{l}-0.83^{* *} \\
(0.31) \\
\end{array}$ & $\begin{array}{l}-0.87^{* *} \\
(0.33) \\
\end{array}$ & $\begin{array}{l}-0.87 * \\
(0.33) \\
\end{array}$ \\
\hline $\begin{array}{l}\text { Bus. Cycle (Grwth- } \\
\text { Avg Grwth) }\end{array}$ & $\begin{array}{l}-0.04 \\
(0.21)\end{array}$ & $\begin{array}{l}-0.02 \\
(0.20)\end{array}$ & $\begin{array}{l}-0.08 \\
(0.21)\end{array}$ & $\begin{array}{l}-0.01 \\
(0.20)\end{array}$ & $\begin{array}{l}-0.06 \\
(0.21)\end{array}$ & $\begin{array}{l}-0.11 \\
(0.20)\end{array}$ & $\begin{array}{l}-0.09 \\
(0.20)\end{array}$ \\
\hline $\begin{array}{l}\text { Log Real GDP per } \\
\text { capita }\end{array}$ & $\begin{array}{l}-5.22^{* *} \\
(1.08) \\
\end{array}$ & $\begin{array}{l}-5.41^{* *} \\
(1.21)\end{array}$ & $\begin{array}{l}-5.59^{* *} \\
(1.20) \\
\end{array}$ & $\begin{array}{l}-4.57 * * \\
(1.25)\end{array}$ & $\begin{array}{l}-5.20^{* *} \\
(1.12)\end{array}$ & $\begin{array}{l}-4.74^{* *} \\
(1.27) \\
\end{array}$ & $\begin{array}{l}-4.68^{* *} \\
(1.27) \\
\end{array}$ \\
\hline Log Real GDP & $\begin{array}{l}-1.29 \# \\
(0.66)\end{array}$ & $\begin{array}{l}-0.75 \\
(0.51)\end{array}$ & $\begin{array}{l}-1.33^{*} \\
(0.83)\end{array}$ & $\begin{array}{l}-1.03 \\
(0.52)\end{array}$ & $\begin{array}{l}-1.24^{*} \\
(0.61)\end{array}$ & $\begin{array}{l}-1.15^{*} \\
(0.55)\end{array}$ & $\begin{array}{l}-1.17 * \\
(0.57)\end{array}$ \\
\hline Observations & 815 & 818 & 818 & 816 & 816 & 807 & 808 \\
\hline Adj. R-squared & 0.22 & 0.21 & 0.22 & 0.21 & 0.22 & 0.21 & 0.21 \\
\hline
\end{tabular}

Notes: Baseline sample. OLS estimation. Dependent variable is lead of inflation. **, * and \# denote significant at the 1, 5 and 10 percent level, respectively. Membership size effects for voting members are jointly significant at 4 percent level; the estimates imply a minimum inflation MPC size of 9 members. 
Table 5: Other MPC characteristics

\begin{tabular}{|c|c|c|c|c|}
\hline De Facto Membership & $\begin{array}{l}-1.79 \# \\
(1.04)\end{array}$ & $\begin{array}{l}-2.16^{*} \\
(0.91)\end{array}$ & $\begin{array}{l}-2.04 * \\
(0.95)\end{array}$ & $\begin{array}{l}-1.76 \# \\
(1.03)\end{array}$ \\
\hline De Facto Membership Squared & $\begin{array}{r}0.09 \# \\
(0.05)\end{array}$ & $\begin{array}{r}0.11^{*} \\
(0.05)\end{array}$ & $\begin{aligned} 0.10^{*} \\
(0.05)\end{aligned}$ & $\begin{array}{r}0.09 \# \\
(0.05)\end{array}$ \\
\hline Government Representatives & $\begin{array}{l}-2.99 * \\
(1.37)\end{array}$ & & & $\begin{array}{l}-2.69 \# \\
(1.40)\end{array}$ \\
\hline Regional Representatives & & $\begin{array}{c}0.33 \\
(0.95)\end{array}$ & & $\begin{array}{c}0.15 \\
(0.99)\end{array}$ \\
\hline Industry Representatives & & & $\begin{array}{l}-1.86 \# \\
(0.97) \\
\end{array}$ & $\begin{array}{l}-0.84 \\
(0.89)\end{array}$ \\
\hline $\begin{array}{l}\text { De Jure Quant. Monetary } \\
\text { Target }\end{array}$ & $\begin{array}{c}-14.4^{* *} \\
(4.2)\end{array}$ & $\begin{array}{c}-14.3^{* *} \\
(4.3) \\
\end{array}$ & $\begin{array}{c}-14.4^{* *} \\
(4.2) \\
\end{array}$ & $\begin{array}{c}-14.4^{* *} \\
(4.2) \\
\end{array}$ \\
\hline Quant. Monetary Success & $\begin{array}{l}-3.07 * * \\
(0.92)\end{array}$ & $\begin{array}{l}-3.15^{* *} \\
(0.96)\end{array}$ & $\begin{array}{l}-3.02 * * \\
(0.94)\end{array}$ & $\begin{array}{c}-2.99 * * \\
(0.95)\end{array}$ \\
\hline Openness (\% GDP) & $\begin{array}{l}0.010 \\
(0.007)\end{array}$ & $\begin{array}{c}0.002 \\
(0.007)\end{array}$ & \begin{tabular}{|c|}
0.008 \\
$(0.008)$ \\
\end{tabular} & $\begin{array}{c}0.011 \\
(0.007)\end{array}$ \\
\hline Budget (\% GDP) & $\begin{array}{l}-0.80^{*} \\
(0.32)\end{array}$ & $\begin{array}{l}-0.83 * * \\
(0.32)\end{array}$ & $\begin{array}{l}-0.83^{* *} \\
(0.31)\end{array}$ & $\begin{array}{l}-0.80 * \\
(0.33)\end{array}$ \\
\hline $\begin{array}{l}\text { Business Cycle } \\
\text { (Growth -Avg Growth) }\end{array}$ & $\begin{array}{l}-0.11 \\
(0.21)\end{array}$ & $\begin{array}{l}-0.09 \\
(0.21)\end{array}$ & $\begin{array}{l}-0.10 \\
(0.21) \\
\end{array}$ & $\begin{array}{l}-0.11 \\
(0.21)\end{array}$ \\
\hline Log Real GDP per capita & $\begin{array}{l}-6.19 * * \\
(1.36) \\
\end{array}$ & $\begin{array}{l}-5.35 * * \\
(1.14) \\
\end{array}$ & \begin{tabular}{|l}
$-5.51 * *$ \\
$(1.18)$ \\
\end{tabular} & $\begin{array}{l}-6.19 * * \\
(1.36) \\
\end{array}$ \\
\hline Log Real GDP & $\begin{array}{l}-1.36 \# \\
(0.81) \\
\end{array}$ & $\begin{array}{l}-1.55^{*} \\
(0.79)\end{array}$ & $\begin{array}{l}-1.41^{*} \\
(0.78) \\
\end{array}$ & $\begin{array}{l}-1.33 \\
(0.84)\end{array}$ \\
\hline Observations & 815 & 815 & 815 & 815 \\
\hline Adj. R-squared & 0.23 & 0.23 & 0.23 & 0.23 \\
\hline
\end{tabular}

Notes: Baseline sample. OLS estimation. Dependent variable is lead of inflation. ${ }^{* *}, *$ and \# denote significant at the 1,5 and 10 percent level, respectively. 
Table 6: MPC Membership size and quantitative targets

\begin{tabular}{|l|l|l|l|}
\hline De Facto Membership & $-2.12^{*}$ & $-2.15^{*}$ & $-2.13^{*}$ \\
& $(0.89)$ & $(0.89)$ & $(0.88)$ \\
\hline De Facto Membership Squared & $0.10^{*}$ & $0.10^{*}$ & $0.10^{*}$ \\
& $(0.04)$ & $(0.04)$ & $(0.04)$ \\
\hline Dummy for Large Committees & $-14.4^{* *}$ & -1.43 & $-14.5^{* *}$ \\
(>10 Members) & $(4.4)$ & $(2.96)$ & $(4.3)$ \\
\hline De Jure Quant. Monetary & $-15.2^{* *}$ & $-13.7^{* *}$ & $-15.1^{* *}$ \\
Target & $(4.4)$ & $(4.2)$ & $(4.5)$ \\
\hline De Jure Quant. Monetary & $17.4^{* *}$ & & $16.9^{* *}$ \\
Target Large Committee & $(5.1)$ & & $(5.4)$ \\
\hline Quant. Monetary Success & $-3.22^{* *}$ & $-4.04^{* *}$ & $-3.33^{* *}$ \\
& $(0.96)$ & $(1.13)$ & $(1.13)$ \\
\hline Quant. Monetary Success $\times$ & & $3.74 \#$ & 0.55 \\
Large Committee & & $(1.96)$ & $(1.46)$ \\
\hline Openness (\% GDP) & 0.003 & 0.003 & 0.003 \\
& $(0.007)$ & $(0.007)$ & $(0.007)$ \\
\hline Budget (\% GDP) & $-0.82^{* *}$ & $-0.83^{* *}$ & $-0.82^{* *}$ \\
& $(0.31)$ & $(0.31)$ & $(0.31)$ \\
\hline Business Cycle & -0.13 & -0.09 & -0.13 \\
(Growth -Avg Growth) & $(0.20)$ & $(0.21)$ & $(0.20)$ \\
\hline Log Real GDP per capita & $-5.43^{* *}$ & $-5.40^{* *}$ & $-5.43^{* *}$ \\
& $(1.12)$ & $(1.13)$ & $(1.12)$ \\
\hline Log Real GDP & $-1.49^{*}$ & $-1.49 \#$ & $-1.49 \#$ \\
& $(0.76)$ & $(0.76)$ & $(0.76)$ \\
\hline & & & \\
\hline Observations & 815 & 815 & 815 \\
\hline Adj. R-squared & 0.23 & 0.23 & 0.23 \\
\hline
\end{tabular}

Notes: OLS estimation. Dependent variable is lead of inflation. **, * and \# denote significant at the 1,5 and 10 percent level, respectively. 
Many central bank laws also specify the composition of the decision-making body. For instance, a frequent restriction is the presence of one or more government representatives in the MPC. Other central bank laws may require the presence of regional or industry representatives (such as, for instance, a delegate from the national banking association). In Table 5, we examine the impact of these restrictions on inflation. More specifically, we add a separate dummy variable for the de facto presence of each category of representatives. While we find no significant effect for the presence of regional delegates in the committee, our empirical findings suggest that central banks with required government representation in the MPC achieve, on average, lower inflation. This result, which is in contrast to the literature on central bank independence ${ }^{17}$, seems to suggest hat membership of government representatives in the decision-making body of a central bank is not automatically linked with a governmentdominated, inflation-prone monetary regime. We obtain similar (though economically smaller and statistically weaker) results for the presence of industry representatives. In a joint estimation, however, only the government representative effect remains of borderline significance.

Finally, Table 6 examines the possible interaction between the size of a central bank committee and quantitative targets in monetary policy. Fatas, Mihov, and Rose (2007) argue that both having established and meeting a quantitative goal for monetary policy is robustly associated with lower inflation. We explore whether MPC size possibly affects inflation through changing the effectiveness of the link between policy targets and economic outcomes; that is, we examine whether the effects of having and hitting a quantitative target differ for MPCs of different membership sizes.

To investigate this question, we distinguish between large and small MPCs. More specifically, we define a dummy variable that takes the value of one if a given MPC has more than ten members and, thus, is 'too large' by the standards of our earlier results. This dummy variable is then interacted with the variables signaling the presence of a monetary target and whether the target is hit and added to our default model. The results suggest that having a quantitative target may no longer be effective in reducing inflation when the MPC is too large: while the declared target dummy remains significantly negative, the coefficient on the interaction term with the large MPCs dummy variable is significantly positive and quantitatively larger. Thus, the inflation-lowering effect of having a transparent target for monetary policy is strongest for small central bank boards with 10 or fewer members. Similarly, hitting a monetary target proves to be particularly helpful for achieving low inflation when the board is small in size, though this effect is smaller in both magnitude and statistical significance.

\section{$\underline{\text { 5. Conclusion }}$}

There is a growing interest in central bank design and especially the optimal size of the central bank's monetary policy decision-making body. Empirically, the membership size of Monetary Policy Committees (MPCs) differs considerably across countries and, to a lower extent, also varies over time. However, while there is a broad consensus that groups make better decisions than individuals, there is little agreement on how large the MPC should be. Theory suggests that the net benefits of MPC size are decreasing as more members are added, mainly because decision-making costs and externalities in information processing gain in importance. Since the precise magnitude of these forces, however, depends on a variety of factors, the efficient size of a MPC is likely to vary across countries.

\footnotetext{
${ }^{17}$ See, for instance, Berger, de Haan, and Eijffinger (2001) for a survey.
} 
This paper adds to the debate from an empirical perspective, exploring the association between MPC size and the economic outcomes of monetary policy. To analyze this issue, we compiled a new data set that characterizes MPCs in over thirty countries from 1960 through 2000. Our data set contains information on the de jure and de facto membership size, the turnover in membership and the membership composition of a central bank's MPC. We then use all these measures to examine the effects of MPC design on inflation (and other economic outcomes), after controlling for other economic and institutional factors.

In our empirical analysis, we find a U-shaped relationship between MPC size and inflation. Our estimates suggest that the minimum level of inflation is reached at MPC sizes between seven and ten members, depending on the regression specification. Qualitatively similar results are obtained for inflation variability and output growth. While there are also some indications that MPC size influences the success of monetary targeting regimes, there is little evidence that MPC membership turnover and the membership composition of the MPC shape economic outcomes. Overall, our results strongly confirm that the membership size of a central bank's decision-making body is an important feature of central bank design. 


\section{References:}

Berger, Helge. 2002. “The ECB and Euro-Area Enlargement,” IMF Working Paper 02/175.

Berger, Helge. 2006. “Optimal Central Bank Design: Benchmarks for the ECB,” Review of International Organizations, 1 (3): 207-335.

Berger, Helge, Jakob de Haan, and Sylvester Eijffinger. 2001. “Central Bank Independence: An Update of Theory and Evidence,” Journal of Economic Surveys.15 (February): 3-40.

Berger, Helge, Volker Nitsch, and Tonny Lybek. 2008. "Central Bank Boards around the World: Why Does Membership Size Differ?” European Journal of Political Economy. (forthcoming).

Berk, Jan Marc, and Beata K. Bierut. 2004. “The Effects of Learning in Interactive Monetary Policy Committees,” Netherlands Central Bank MEB Series 2004-01.

Blinder, Alan. 1998. Central Banking in Theory and Practice. Cambridge, Massachusetts: MIT Press.

Blinder, Alan. 2007. “On the Design of Monetary Policy Committees,” CEPS Working Paper 153.

Blinder, Alan and John Morgan. 2005. "Are Two Heads Better Than One? Monetary Policy by Committee,” Journal of Money, Credit and Banking. 37 (5): 798-811.

Blinder, Alan and John Morgan. 2007. "Leadership in Groups: A Monetary Policy Experiment”, CEPS Working Paper 151.

Campillo, Marta and Jeffrey Miron. 1997. “Why Does Inflation Differ Across Countries?” in Christina Romer and David Romer (eds.) Reducing Inflation: Motivation and Strategy.

Chicago: University of Chicago Press.

Cukierman, Alex. 1992. Central Bank Strategy, Credibility, and Independence: Theory and Evidence. Cambridge, MA: MIT Press.

Cukierman, Alex, Steven Webb and Bilin Neyapti. 1992. "Measuring the Independence of Central Banks and Its Effect on Policy Outcomes," World Bank Economic Review. 6 (September): 353-398.

de Haan, Jakob and Willem Kooi. 2000. "Does Central Bank Independence Really Matter? New Evidence for Developing Countries Using a New Indicator,” Journal of Banking and Finance. 24 (April): 643-664.

Deutsche Bundesbank. 1992. "Restructuring the Bundesbank,” Monthly Report, August: 4853.

Dreher, Axel, Jan-Egbert Sturm, and Jakob de Haan. 2007. "Does High Inflation Cause Central Bankers to Lose their Job? Evidence Based on a New Data Set," CESifo Working Paper 2045. 
Erhart, Szilárd, Harmen Lehment, and Jose Luis Vasquez-Paz. 2007. “Monetary Policy Committee Size and Inflation Volatility”, Kiel Working Paper 1377.

Erhart, Szilárd and Jose Luis Vasquez-Paz. 2007. “Optimal Monetary Policy Committee Size: Theory and Cross Country Evidence”, Kiel Advanced Studies Working Paper 439.

Fatas, Antonio, Ilian Mihov, and Andrew K. Rose. 2007. "Quantitative Goals for Monetary Policy,” Journal of Money, Credit and Banking. 39 (August): 1163-1176.

Fry, Maxwell, Deanne Julius, Lavan Mahadeva, Sandra Roger, and Gabriel Sterne (2000), Key Issues in the Choice of Monetary Policy Framework, in Lavan Mahadeva and Gabriel Sterne (eds.) Monetary Frameworks in a Global Context. London: Routledge, 1-216.

Fujiki, Hiroshi. 2005. "The Monetary Policy Committee and the Incentive Problem: A Selective Survey,” Monetary and Economic Studies. (October): 37-82.

Gerlach-Kristen, Petra. 2006. "Monetary Policy Committees and Interest-Rate Setting,” European Economic Review. 50 (2): 487-507.

Gersbach, Hans and Bernhard Pachl. 2004. "Flexible Rules for Central Banks,” CEPR Discussion Paper 4398

Gerling, Kerstin, Hans Peter Grüner, Alexandra Kiel, and Elisabeth Schulte. 2005.

"Information Acquisition and Decision Making in Committees: A Survey,” European Journal of Political Economy. 21 (3): 563-597.

Göhlmann, Silja and Roland Vaubel. 2007. "The Educational and Occupational Background of Central Bankers and Its Effect on Inflation: An Empirical Analysis,” European Economic Review. 51 (May): 925-941.

Goodfriend, Marvin. 2005. “Comment on Fujiki,” Monetary and Economic Studies. (October): 83-87.

Levy-Yeyati, Eduardo and Federico Sturzenegger. 2001. "Exchange Rate and Economic Performance,” IMF Staff Papers. 47 (Special): 62-98.

Levy-Yeyati, Eduardo and Federico Sturzenegger. 2003. "To Float or to Fix: Evidence on the Impact of Exchange Rate Regimes on Growth,” American Economic Review. 93 (September): 1173-1193.

Lombardelli, Clare, James Proudman, and James Talbot. 2005. "Committees versus Individuals: An Experimental Analysis of Monetary Policy Decision Making,” International Journal of Central Banking. 1 (1): 181-205.

Mishkin, Frederic S. and Klaus Schmidt-Hebbel. 2007. "Does Inflation Targeting Make a Difference?” NBER Working Paper 12876.

Riboni, Alessandro, and Francisco Ruge-Murcia. 2006. "The Dynamic (In)efficiency of Monetary Policy by Committee,” Université de Montréal Working Paper 2006-2. 
Sibert, Anne. 2006. “Central Banking by Committee,” International Finance. 9 (August): 145168.

Sturm, Jan-Egbert and Jakob de Haan. 2001. "Inflation in Developing Countries: Does Central Bank Independence Matter? New Evidence Based on a New Data Set,” Ifo Studien. 47 (4): 389-403.

Temple, Jonathan. 1998. "Central Bank Independence and Inflation: Good News and Bad News,” Economics Letters. 61 (November): 215-219.

UK House of Commons. 2007. The Monetary Policy Committee of the Bank of England: Ten Years On. London: The Stationery Office Limited.

Vandenbussche, Jérôme. 2006. "Elements of Optimal Monetary Policy Committee Design,” IMF Working Paper 06/277.

von Hagen, Jürgen and Matthias Brückner. 2001. "Monetary Policy in Unknown Territory, The European Central Bank in the Early Years,” ZEI Discussion Paper B18. 
$\underline{\text { Appendix 1: Data sources and variable list }}$

\begin{tabular}{|c|c|c|}
\hline Variable: & Description: & Source: \\
\hline Inflation & CPI inflation, $\%$, from IFS & Fatas, Mihov \& Rose \\
\hline Inflation Variability & $\begin{array}{l}\text { Standard deviation of inflation over } \\
\text { (non-overlapping) five-year intervals }\end{array}$ & Own compilation \\
\hline Output Growth & Real GDP growth, \% & Own compilation \\
\hline De Facto Membership & $\begin{array}{l}\text { Number of actual members in the } \\
\text { MPC }\end{array}$ & Own compilation \\
\hline De Jure Membership & $\begin{array}{l}\text { Number of members in the MPC as } \\
\text { defined in the central bank law }\end{array}$ & Own compilation \\
\hline $\begin{array}{l}\text { Membership Turnover } \\
\text { Rate }\end{array}$ & $\begin{array}{l}\text { Fraction of membership changes in } \\
\text { total membership of MPC }\end{array}$ & Own compilation \\
\hline $\begin{array}{l}\text { Governor Turnover } \\
\text { Dummy }\end{array}$ & $\begin{array}{l}\text { Dummy variable if central bank } \\
\text { governor changed }\end{array}$ & Own compilation \\
\hline $\begin{array}{l}\text { Government } \\
\text { Representatives }\end{array}$ & $\begin{array}{l}\text { Dummy variable if MPC comprises } \\
\text { government representative(s) }\end{array}$ & Own compilation \\
\hline Regional Representatives & $\begin{array}{l}\text { Dummy variable if MPC comprises } \\
\text { regional representative(s) }\end{array}$ & Own compilation \\
\hline Industry Representatives & $\begin{array}{l}\text { Dummy variable if MPC comprises } \\
\text { industry representative(s) }\end{array}$ & Own compilation \\
\hline $\begin{array}{l}\text { De Jure Quant. Monetary } \\
\text { Target }\end{array}$ & $\begin{array}{l}\text { Dummy variable if the country had a } \\
\text { quantitative monetary policy target }\end{array}$ & Fatas, Mihov \& Rose \\
\hline Quant. Monetary Success & $\begin{array}{l}\text { Dummy variable if the country hit its } \\
\text { de jure quantitative target }\end{array}$ & Fatas, Mihov \& Rose \\
\hline Openness (\% GDP) & Trade, \% GDP, from PWT & Fatas, Mihov \& Rose \\
\hline Budget (\% GDP) & $\begin{array}{l}\text { Government budget balance, \% GDP, } \\
\text { from IFS \& WDI }\end{array}$ & Fatas, Mihov \& Rose \\
\hline $\begin{array}{l}\text { Business Cycle } \\
\text { (Growth -Avg Growth) }\end{array}$ & $\begin{array}{l}\text { Difference between real GDP growth } \\
\text { and average (country-specific) GDP } \\
\text { growth, percentage points }\end{array}$ & Fatas, Mihov \& Rose \\
\hline Log Real GDP per capita & $\begin{array}{l}\text { Log of real GDP per capita (chain } \\
\text { method), from PWT }\end{array}$ & Fatas, Mihov \& Rose \\
\hline Log Real GDP & $\begin{array}{l}\text { Log of real GDP, computed from per } \\
\text { capita GDP and population, from } \\
\text { PWT }\end{array}$ & Fatas, Mihov \& Rose \\
\hline
\end{tabular}




\section{Appendix 2: Countries in sample}

Argentina

Australia

Austria

Belgium

Botswana

Brazil

Canada

Denmark

Finland

France

Germany

Iceland

Ireland

Israel

Italy

Japan

Korea

Malaysia

Mauritius

Netherlands

New Zealand

Norway

Pakistan

Portugal

Singapore

Spain

Sweden

Switzerland

Thailand

Trinidad \& Tobago

Turkey

U.K.

U.S.A. 


\section{CESifo Working Paper Series}

for full list see www.cesifo-group.org/wp

(address: Poschingerstr. 5, 81679 Munich, Germany, office@cesifo.de)

2208 Frederick van der Ploeg and Steven Poelhekke, Globalization and the Rise of MegaCities in the Developing World, February 2008

2209 Sara Biancini, Regulating National Firms in a Common Market, February 2008

2210 Jin Cao and Gerhard Illing, Liquidity Shortages and Monetary Policy, February 2008

2211 Mathias Kifmann, The Design of Pension Pay Out Options when the Health Status during Retirement is Uncertain, February 2008

2212 Laszlo Goerke, Tax Overpayments, Tax Evasion, and Book-Tax Differences, February 2008

2213 Jun-ichi Itaya and Heinrich W. Ursprung, Price and Death, February 2008

2214 Valentina Bosetti, Carlo Carraro and Emanuele Massetti, Banking Permits: Economic Efficiency and Distributional Effects, February 2008

2215 Assar Lindbeck, Mårten Palme and Mats Persson, Social Interaction and Sickness Absence, February 2008

2216 Gary E. Bolton and Axel Ockenfels, The Limits of Trust in Economic Transactions Investigations of Perfect Reputation Systems, February 2008

2217 Hartmut Egger and Peter Egger, The Trade and Welfare Effects of Mergers in Space, February 2008

2218 Dorothee Crayen and Joerg Baten, Global Trends in Numeracy 1820-1949 and its Implications for Long-Run Growth, February 2008

2219 Stephane Dees, M. Hashem Pesaran, L. Vanessa Smith and Ron P. Smith, Identification of New Keynesian Phillips Curves from a Global Perspective, February 2008

2220 Jerome L. Stein, A Tale of Two Debt Crises: A Stochastic Optimal Control Analysis, February 2008

2221 Michael Melvin, Lukas Menkhoff and Maik Schmeling, Automating Exchange Rate Target Zones: Intervention via an Electronic Limit Order Book, February 2008

2222 Raymond Riezman and Ping Wang, Preference Bias and Outsourcing to Market: A Steady-State Analysis, February 2008

2223 Lars-Erik Borge and Jørn Rattsø, Young and Old Competing for Public Welfare Services, February 2008 
2224 Jose Apesteguia, Steffen Huck, Jörg Oechssler and Simon Weidenholzer, Imitation and the Evolution of Walrasian Behavior: Theoretically Fragile but Behaviorally Robust, February 2008

2225 Walter Krämer, Long Memory with Markov-Switching GARCH, February 2008

2226 António Afonso and Christophe Rault, What do we really Know about Fiscal Sustainability in the EU? A Panel Data Diagnostic, February 2008

2227 Sergey M. Kadochnikov and Igor M. Drapkin, Market Structure, Technological Gap and Vertical Linkage Effects from Foreign Direct Investment, February 2008

2228 Guglielmo Maria Caporale, Davide Ciferri and Alessandro Girardi, Fiscal Shocks and Real Exchange Rate Dynamics: Some Evidence for Latin America, February 2008

2229 Scott Alan Carson, Geography and Insolation in $19^{\text {th }}$ Century US African-American and White Statures, February 2008

2230 Wolfgang Buchholz and Jan Schumacher, Discounting and Welfare Analysis Over Time: Choosing the $\eta$, February 2008

2231 M. Hashem Pesaran, Christoph Schleicher and Paolo Zaffaroni, Model Averaging in Risk Management with an Application to Futures Markets, February 2008

2232 Wilhelm Kohler, Offshoring: Why Do Stories Differ?, February 2008

2233 Stefan Bach, Giacomo Corneo and Viktor Steiner, Effective Taxation of Top Incomes in Germany, 1992-2002, February 2008

2234 Robert S. Chirinko, $\sigma$ : The Long And Short Of It, February 2008

2235 Volker Grossmann and Holger Strulik, Should Continued Family Firms Face Lower Taxes than other Estates?, February 2008

2236 Guido Tabellini, The Scope of Cooperation: Values and Incentives, February 2008

2237 Heinrich W. Ursprung and Christian Wiermann, Reputation, Price, and Death: An Empirical Analysis of Art Price Formation, March 2008

2238 Hans Fehr and Christian Habermann, Private Retirement Savings in Germany: The Structure of Tax Incentives and Annuitization, March 2008

2239 Joseph Francois and Ian Wooton, Market Structure and Market Access, March 2008

2240 Hiroyuki Kasahara and Beverly Lapham, Productivity and the Decision to Import and Export: Theory and Evidence, March 2008

2241 Gary E. Bolton and Axel Ockenfels, Does Laboratory Trading Mirror Behavior in Real World Markets? Fair Bargaining and Competitive Bidding on EBay, March 2008 
2242 Atsushi Oshima, B. Ravikumar and Raymond Riezman, Entrepreneurship, Organization Capital and the Evolution of the Firm, March 2008

2243 Walter Krämer and Sebastian Schich, Large-Scale Disasters and the Insurance Industry, March 2008

2244 Leif Danziger, Adjustment Costs, Inventories and Output, March 2008

2245 Anne van Aaken, Lars P. Feld and Stefan Voigt, Power over Prosecutors Corrupts Politicians: Cross Country Evidence Using a New Indicator, March 2008

2246 Hans-Christian Heinemeyer, Max-Stephan Schulze and Nikolaus Wolf, Endogenous Borders? The Effects of New Borders on Trade in Central Europe 1885-1933, March 2008

2247 Johannes Becker and Clemens Fuest, Tax Competition - Greenfield Investment versus Mergers and Acquisitions, March 2008

2248 Giorgio Bellettini and Hubert Kempf, Why not in your Backyard? On the Location and Size of a Public Facility, March 2008

2249 Jose Luis Evia, Roberto Laserna and Stergios Skaperdas, Socio-Political Conflict and Economic Performance in Bolivia, March 2008

2250 Bas Jacobs and A. Lans Bovenberg, Optimal Taxation of Human Capital and the Earnings Function, March 2008

2251 Jan-Egbert Sturm and Timo Wollmershäuser, The Stress of Having a Single Monetary Policy in Europe, March 2008

2252 Guido Schwerdt, Labor Turnover before Plant Closure: 'Leaving the Sinking Ship' vs. 'Captain Throwing Ballast Overboard', March 2008

2253 Keith E. Maskus and Shuichiro Nishioka, Development-Related Biases in Factor Productivities and the HOV Model of Trade, March 2008

2254 Jeremy Edwards and Sheilagh Ogilvie, Contract Enforcement, Institutions and Social Capital: the Maghribi Traders Reappraised, March 2008

2255 Imed Drine and Christophe Rault, Purchasing Power Parity for Developing and Developed Countries. What can we Learn from Non-Stationary Panel Data Models?, March 2008

2256 Scott Alan Carson, Health, Wealth and Inequality: a Contribution to the Debate about the Relationship between Inequality and Health, March 2008

2257 C.A.E. Goodhart, The Regulatory Response to the Financial Crisis, March 2008

2258 Stefan Bauernschuster, Oliver Falck and Stephan Heblich, The Impact of Continuous Training on a Firm's Innovations, March 2008 
2259 Michael Grimm and Stephan Klasen, Geography vs. Institutions at the Village Level, March 2008

2260 Fwu-Ranq Chang, Property Insurance, Portfolio Selection and their Interdependence, March 2008

2261 J. Atsu Amegashie and Marco Runkel, The Paradoxes of Revenge in Conflicts, March 2008

2262 Hans Jarle Kind, Marko Koethenbuerger and Guttorm Schjelderup, Efficiency Enhancing Taxation in Two-sided Markets, March 2008

2263 M. Hashem Pesaran, Til Schuermann and L. Vanessa Smith, Forecasting Economic and Financial Variables with Global VARs, March 2008

2264 Volker Grossmann, Entrepreneurial Innovation and Sustained Long-run Growth without Weak or Strong Scale Effects, March 2008

2265 Robert S. Chirinko and Huntley Schaller, The Irreversibility Premium, March 2008

2266 Andrea Galeotti and José Luis Moraga-González, Platform Intermediation in a Market for Differentiated Products, April 2008

2267 Torben M. Andersen and Michael Svarer, The Role of Workfare in Striking a Balance between Incentives and Insurance in the Labour Market, April 2008

2268 Harald Badinger, Cyclical Fiscal Policy, Output Volatility, and Economic Growth, April 2008

2269 Thomas Aronsson and Erkki Koskela, Outsourcing and Optimal Nonlinear Taxation: A Note, April 2008

2270 Gary E. Bolton, Claudia Loebbecke and Axel Ockenfels, How Social Reputation Networks Interact with Competition in Anonymous Online Trading: An Experimental Study, April 2008

2271 Nikolaus Wolf, Scylla and Charybdis. Explaining Europe's Exit from Gold, January 1928 - December 1936, April 2008

2272 Michael Funke and Marc Gronwald, The Undisclosed Renminbi Basket: Are the Markets Telling us something about where the Renminbi - US Dollar Exchange Rate is Going?, April 2008

2273 Thor Olav Thoresen and Annette Alstadsæter, Shifts in Organizational Form under a Dual Income Tax System, April 2008

2274 Helge Berger and Volker Nitsch, Too many Cooks? Committees in Monetary Policy, April 2008 